Volume-V, Issue-02, July-December, 2010

\title{
Satisfaction of Debit Card Users in Bangladesh: A Study on Some Private Commercial Banks
}

\author{
AFROZA PARVIN ${ }^{1}$ \\ MD. SHAJAHAN HOSSAIN ${ }^{2}$
}

\begin{abstract}
Banks are the financial institutions that provide different services through depositproducts, loan-products, etc. Debit card is one of the prominent card services related to deposit-products, which offers customers 24- hours banking access, such as cash withdrawal, purchasing of goods and services, etc. But sometimes customers are to face many problems i.e. non-availability of Taka, network problem, lack of desired value denominated notes and so on. This paper reveals how much debit card users of banks in Bangladesh are satisfied. Findings reveal that on an average debit card users are satisfied. Regarding availability of Taka in the ATM booth, users are most satisfied and regarding network service users are least satisfied. By improving network service, providing receipt after transactions and solving of problems promptly, banks can make their debit card users fully satisfied.
\end{abstract}

Key words: Debit card, Customer satisfaction, Electronic banking.

\section{INTRODUCTION}

This is the age of globalization and financial institutions are slowly moving from brick and mortar (physical branches) to click and brick (Banstola 2007). Since the beginning, private banks have been trying their best to keep their customers satisfied. ATM card service is one of their latest services and it let customers bank any time. ATM was first introduced in 1967 at Barclays Bank in Enfield in London by the Scottish Scientist Shephard Baron. In Khulna division of Bangladesh it was first introduced by Standard Chartered Bank. The history of debit card implies that the concept of debit card is not new rather it dates back to around 20 years, which highlighted the introduction of e-commerce and alternative means of payment (info.com).

\footnotetext{
${ }^{1}$ Senior Lecturer, Department of Business Administration, Northern University Bangladesh.

${ }^{2}$ Senior Lecturer, Department of General Education, Northern University Bangladesh.
} 
Debit card is a great financial tool, a source of plastic money, which is used everyday for making life easier by giving access to cash while transacting. As a part of "electronic banking," the importance of debit card has been increased day by day. In this paper the level of satisfaction of debit card users has been examined. This paper aims at help the sample banks to find out their customers' satisfaction level as well as motivational factors and ways to provide modern debit card services.

\subsection{Objectives of the Study}

The objectives of this study are as follows:

1. To measure the satisfaction level of debit card users of different private commercial banks.

2. To find out major problems faced by the card users.

3. To recommend some policy measures for the better service delivery and customer retention with a view to achieving wealth maximization goal.

\subsection{Rationale of the Study}

Customer satisfaction gives an indication of how successful the organization is for its products or services in the market. Because it is said that customer is the king. All activities of the banks are directed towards customer satisfactionwhich leads to customer retention--a key factor for achieving the goal of banking business. From this study the selected banks will know their customers' satisfaction level from using debit card. It will also help them to understand whether their policy is right or not to retain the customers. Some recommendations are made on the basis of the measurement of satisfaction for better card services in future.

\section{RESEARCH METHODOLOGY}

Customer satisfaction levels can be measured using survey techniques and questionnaires. Every research is completed after applying few methods to fulfill the objectives of the research.

\subsection{Data Collection}

This study has used both primary and secondary data. Primary data are collected by interviewing the cardholders using a questionnaire (which includes both openended and closed-ended questions). The sample size of the study is 200 selected from nine private commercial banks located in Khulna city using convenient sampling method. This study considers the following factors to measure the customer satisfaction: availability of ATM booth, service quality, different value using denominated notes, availability of transaction receipt, availability of money, 
etc. For measuring factor basis satisfaction, a 5 point Likert-type scale has been used ranging from highly dissatisfied (1) to highly satisfied (5). It is assumed that $100 \%=5=$ highly satisfied. So, the class interval will be like: highly dissatisfied $=$ $0 \%-19 \%$, dissatisfied $=20 \%-39 \%$, neutral $=40 \%-59 \%$, satisfied $=60 \%-79 \%$ and highly satisfied $=80 \%-100 \%$. The class interval is $20 \%$.

To ensure the timely questionnaire, a pilot survey has been conducted. Then the final questionnaire has been made up with the correction in case of need. Finally, the questionnaire survey has been completed through the interview method. Secondary data have been collected from different books, articles, websites, etc.

\subsection{Data Analysis}

To analyze the collected data different statistical tools have been used such as pie chart, bar diagram, tables, etc. are used. To find out the factor basis satisfaction, arithmetic mean has been calculated. On the other hand, to find out overall satisfaction, weighted average satisfaction is calculated.

\section{LITERATURE REVIEW}

This section reviews important literatures relevant to this research problem.

Banstola (2007) has shown the benefits and challenges of e-banking practiced in Nepal. This has been done from the bank and customers' point of view. In this study cost, risk exposure, availability of internet connection and diversified expectations of customers are examined.

Huq and Tania (2005) pointed out how the credit card users are satisfied.Islam et al. (2005) find out the satisfaction level of ATM users of HSBC bank. Their study indicates that location, personnel response, quality of currency notes, promptness of card delivery and performance of ATM are positively related to the satisfaction of the customer.

Jabnoun and Al-Tamimi show that service quality in banks is critical for satisfaction and retention of customers.

Khan (2010) explained the effect of ATM service quality on customers using five key ATM service quality factors: convenience, efficient operation, security and privacy, reliability and responsiveness. He finds a strong positive relationship between ATM service quality and customers' satisfaction level.

Mobarek has made an attempt to analyse customer's perception towards ebanking services, quality of e-banking services and the constraints related to this. 
Shamsuddoha, Chowdhury and Ahsan exposed that cash withdrawal, balance inquiry, cash deposit, fund transfer and chequebook requisition are the main services consumed by the customers who use ATM. They also show that 24 hours service accuracy, convenient location, etc. are the main factors of customer satisfaction. Moreover, the same study identifies lack of privacy in transaction, fear of safety and complexity of machine as the matters that draw the customers 'concern.

Shamsuddoha shows the development, structure and features of e-banking in Bangladesh. He mentions credit card, debit card, internet banking, account checking, home banking, tele banking, SWIFT, easy pay machine, etc. as the electronic performance areas.

\subsection{Limitations of the Study}

Every research has some limitations. In conducting this research the following limitations are faced:

1. Sometimes respondents were reluctant to provide information.

2. This study is done by taking samples only from Khulna city, which may not reflect the whole picture of Bangladesh.

\section{ANALYSIS AND FINDINGS}

Gaining high level of customer satisfaction is very important to a business because satisfied customers are most likely to be loyal and to make repeat orders and use a wide range of services offered by a business.

\subsection{Customer and Bank- Specific Analysis and Findings}

Analyses regarding the respondents' age, educational qualification, occupations and so on are presented below.

\section{Age and Educational Qualification of the Respondents}

The study finds that 14 percent users are belong to 15-29 age group, while the highest number of users belong to 25-29 age group. Usage rate decreases with the increase of age, as show in Table 1 . Out of 200 respondents, 176 are male (88 percent) and 24 are female (12 percent). Most of the respondents (50 percent) 
completed their undergraduate program while very few (4 percent) belong to $\mathrm{M}$ Phil. /PhD level.

TABLE 1

AGE AND EDUCATIONAL QUALIFICATION OF THE RESPONDENTS

\begin{tabular}{l|l|l|l}
\hline \multicolumn{1}{c|}{ Age group } & \multicolumn{1}{c}{ Percentage } & Educational Level & Percentage \\
\hline Below 14 & 0 & SSC & 10 \\
$15-19$ & 5 & HSC & 16 \\
$20-24$ & 9 & Undergraduate & 50 \\
$25-29$ & 30 & Postgraduate & 20 \\
$30-34$ & 18 & M Phil./PhD & 04 \\
$35-39$ & 15 & & \\
$40-44$ & 7 & & \\
$45-49$ & 8 & & $100 \%(\mathrm{~N}=200)$ \\
$50-54$ & 5 & & \\
55 and above & 3 & Total & \\
Total & $100 \%(\mathrm{~N}=200)$ & & \\
\hline
\end{tabular}

Source: Own Survey from March 02-15, 2010

\section{Occupation of the Respondents}

Out of 200 respondents, 20 percent are teachers, 10 percent banker and the highest number of respondents (25 percent) are involved in business. Eighteen percent and 15 percent are respectively doctors and students.

Figure 1: Occupation of the respondents

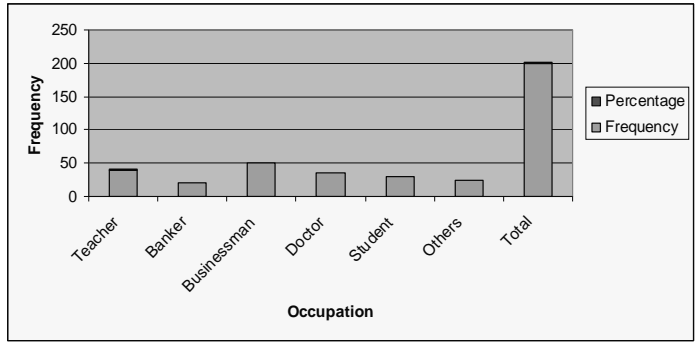

Source: Own Survey 2010. 


\section{Frequency of the Respondents of Sample Banks}

Out of 47 private banks presently operating in Bangladesh, only 9 banks are selected for this study. Highest numbers of respondents (47 percent) are selected from Dutch Bangla Bank Limited and the lowest numbers are selected from Standard Chartered Bank and Arab Bangladesh Bank Limited (2 percent respectively).

TABLE 2

\section{FREQUENCY OF THE RESPONDENTS AMONG SELECTED BANKS}

\begin{tabular}{c|c|c|c}
\hline Name of the Bank & $\begin{array}{c}\text { Percentage of } \\
\text { Respondents }\end{array}$ & $\begin{array}{c}\text { Name of the } \\
\text { Bank }\end{array}$ & $\begin{array}{c}\text { Percentage of } \\
\text { Respondents }\end{array}$ \\
\hline MBL & 15 & PBL & 9 \\
DBBL & 47 & SCB & 2 \\
CBL & 4 & ABBL & 2 \\
EBL & 13 & SJIBL & 4 \\
BBL & 4 & Total & $100 \%(\mathrm{~N}=200)$ \\
\hline
\end{tabular}

Source: Own Survey

\section{Banks' Own Booth in Khulna}

From the survey it is observed that 76 percent banks have their own booth in Khulna, while 24 percent respondents use other bank's booth to use debit card.

Figure 2: Banks' own booth position

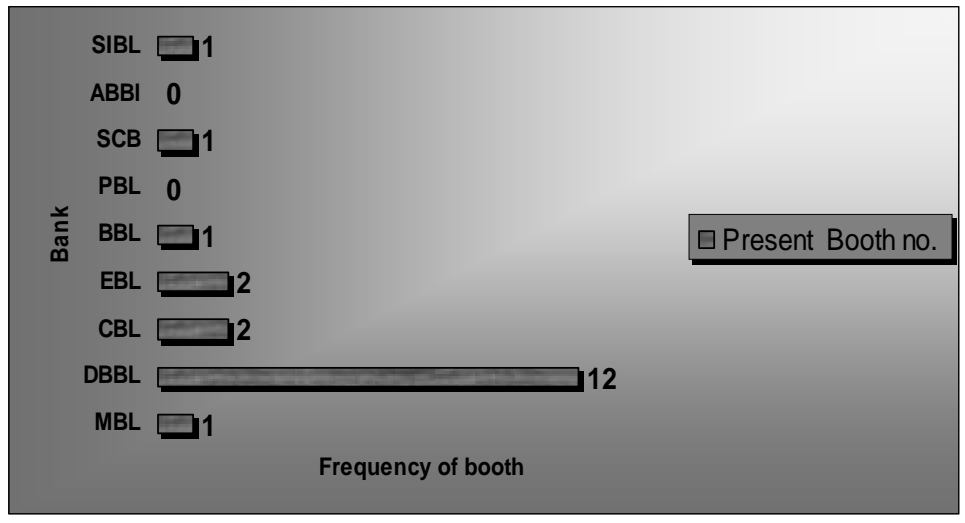

Source: Banks’ website, 2010 


\section{Purpose, Duration and Times of Using Debit Card}

Customers use debit card either for taka withdrawal or for purchase of goods and services or for both. This study shows that 80 percent respondents use debit card for taka withdrawal, while 12 percent use it for purchasing goods and services. Only 8 percent customers use it for both purposes. Duration of debit card use is different for different customers. The study shows that 78 customers are using debit card for 1 year, 86 are using it for 1-2 years and others are using for 3-4 years. There is no user who uses the card for 5 years or more. It is also noteworthy that the usage pattern of customers is different. Some users use it just one time per month while some others use it 4 or move times. This study indicates that 40 percent customers use only 1-2 times per month for taka withdrawal or purchase of goods and services or for both, while 30 percent customers use debit card more than four times for the same purpose.

\section{Cause of Customers' Interest to Use Debit Cardo}

When the customers were asked what factors did motivate them to use debit card, most of them answered that they started to use it as it saves time. There are some other stimuli to encourage customers to use debit card for their transaction. However, there is overlapping of some causes of interest because at the same time more than one factor has influenced a single customer.

Figure 3: Cause of customers' interest to use debit card

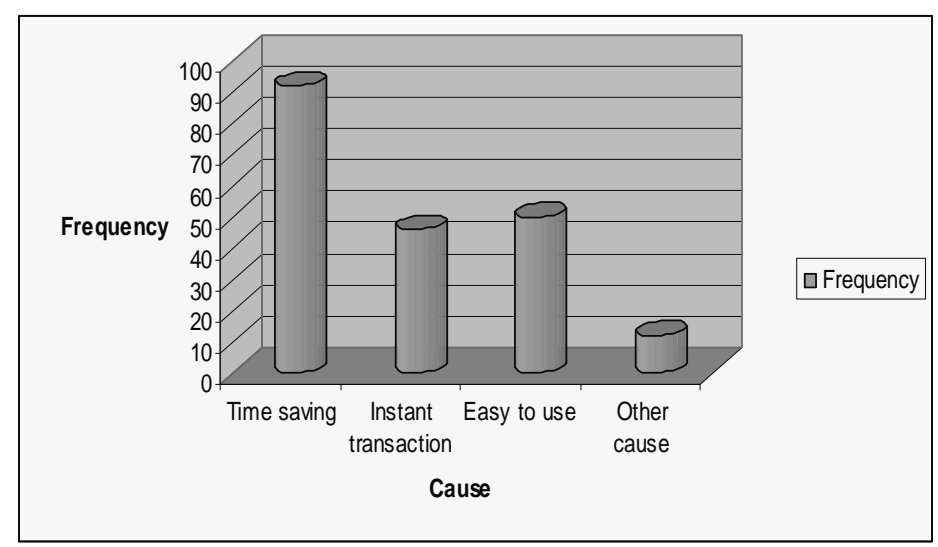

Source: Own Survey, 2010 


\subsection{Problem-Specific Analysis and Findings}

\section{Whether Customers Faced Problems}

Satisfaction or dissatisfaction largely depends upon the problem that customers face when they use any product or consume any service. This is also applicable for debit card. This study shows that 65 percent customers have faced problem during their use of debit card.

Figure 4: Whether Customers Faced Problems

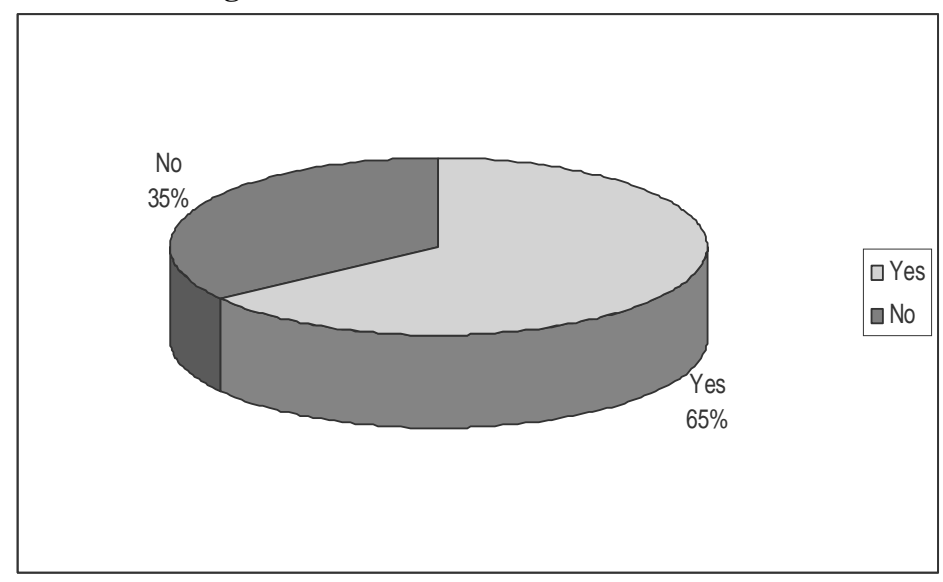

Source: Own Survey, 2010

\section{Nature of Problem}

Problem is different for different customers. Figure 1 shows that 65 percent customers have faced problems. A total of 112 customers have faced the problem of unavailability of taka and receipt in the case of withdrawing taka from the ATM booth. However, it interesting to mention that only 4 customers got fake note during their transaction. Seventy-eight customers did not get small value denominated notes while they wanted to withdraw taka from the booth. "Receipt was available but not taka" 34 customers did agree with this point. It has also happened that a single customer has faced different problems. 
Figure 5: Nature of problem

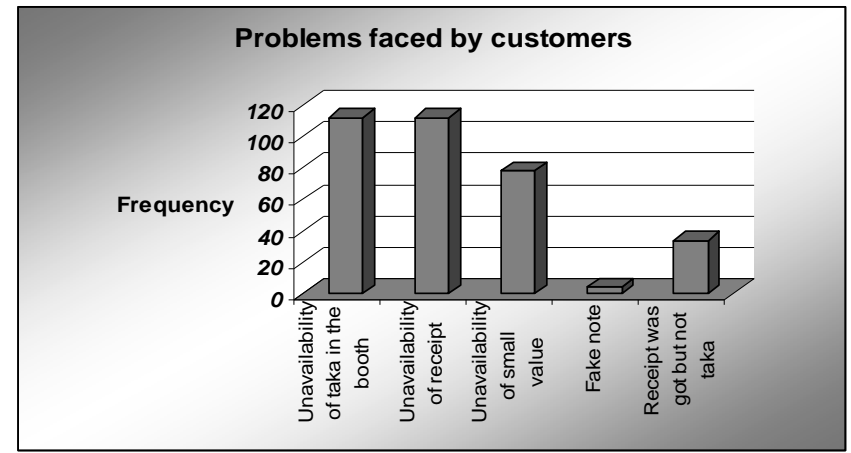

Source: Own Survey, 2010

\section{Problem Bank}

As customers have different types of problems, it is rationale to know in which bank's booth they faced that. The researchers have defined the bank whose customers have face problem for debit card as 'Problem Bank'. It has been found that 54 percent customers of DBBL faced most problems, whereas BBL's customers faced least problems during their debit card use. It is noteworthy that some customers have faced problems in many banks.

Figure 6: Problem bank's customers' frequency

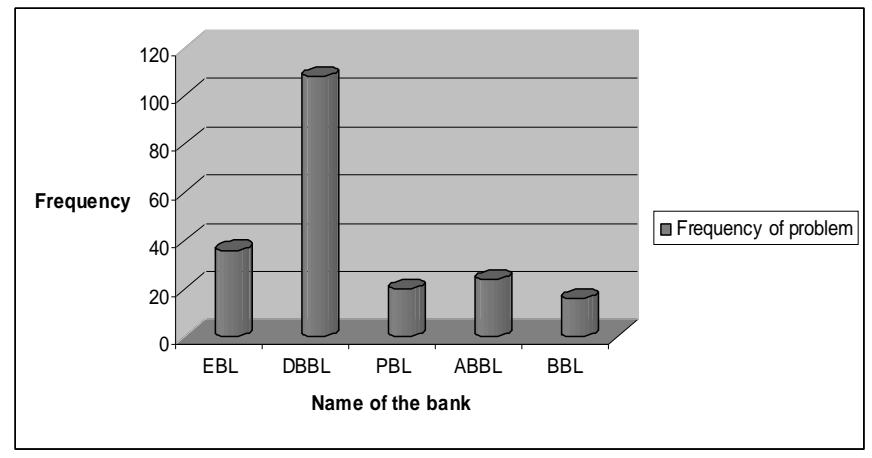

Source: Own Survey, 2010 


\subsection{Satisfaction Factor- Specific Analysis and Findings}

Studies show that users' satisfaction is an essential determinant of success of the technology based delivery channels (Tong 2009, Wu \& Wang 2007). Different factors affect users' satisfaction level differently.Findings from the calculation in Table 5 are discussed below:

\section{Availability of taka in the booth}

People use debit card mostly to withdraw taka. So it is important to have sufficient amount of taka in the booth. This study shows the average position of the taka availability in the booth. In this case the customers are satisfied but not highly as the calculated mean value is $76 \%$.

\section{Different value denominated notes}

Satisfaction among the debit card users depends on many factors. Availability of different value denominated notes is one of the factors. According to the calculated mean value, customers are satisfied though 22 respondents are neutral. Therefore, some banks are lagging behind in this case.

\section{Network service}

Network service is the first and foremost condition to make debit card users satisfied because without network transaction is not possible. This study shows that card users are somewhat satisfied regarding the network service. The mean value is only $62.2 \%$, which is very close to neutral value. It indicates a large member of respondents have faced problem in this connection.

TABLE 5

SATISFACTION LEVEL OF CUSTOMERS AT DIFFERENT FACTORS

\begin{tabular}{|c|c|c|c|c|c|}
\hline Factor & $\begin{array}{c}\text { Highly } \\
\text { Dissatisfied } \\
\text { (1) }\end{array}$ & $\begin{array}{c}\text { Dissatisfied } \\
\text { (2) }\end{array}$ & $\begin{array}{c}\text { Neutral } \\
\text { (3) }\end{array}$ & $\begin{array}{c}\text { Satisfied } \\
\text { (4) }\end{array}$ & $\begin{array}{l}\text { Highly } \\
\text { Satisfied } \\
\quad(5)\end{array}$ \\
\hline Availability of taka in the booth & 0 & 18 & 30 & 126 & 26 \\
\hline Different value denominated notes & 0 & 22 & 34 & 96 & 48 \\
\hline Network service & 20 & 44 & 64 & 38 & 34 \\
\hline Availability of receipt & 12 & 40 & 22 & 86 & 40 \\
\hline Solving of problem by the bank & 0 & 10 & 60 & 112 & 18 \\
\hline Service quality & 0 & 18 & 34 & 130 & 18 \\
\hline Transaction cost & 0 & 52 & 34 & 96 & 18 \\
\hline Purchasing of goods and service & 10 & 22 & 104 & 56 & 8 \\
\hline Availability of bank's booth & 20 & 34 & 42 & 56 & 48 \\
\hline
\end{tabular}

Source: Own Survey, 2010. 


\section{Availability of receipt}

After the transaction, users expect to get receipt to know the remaining balance. The average response is $70 \%$, whice means most of the banks give receipt after transaction and let customers know about their account balance. But it should be mentioned here that 12 respondents are highly dissatisfied.

\section{Solving of problem by the bank}

Customers may face any type of problem during their usage of debit card that needs to be solved as soon as possible by the banks for creating good image. The respondents were satisfied as the average value shows $73.8 \%$.The result indicates banks take care about solving the problems that customers face.

\section{Service quality}

The customers always compare the service of one organization with other. This is why banks try to provide updated and best service to their customers. Regarding the question of service quality, majority respondents expressed their satisfaction.

\section{Transaction cost}

Nowadays customers are very much conscious and they always expect better service at low cost. When they were asked whether they are satisfied in this connection, they agreed $68 \%$ that means they are satisfied for the cost they are paying for debit card transaction.

\section{Purchasing of goods and services}

Debit card is mostly used for two purposes: (i) withdraw taka and (ii) purchase goods and services. It is to be mentioned that only 8 customers are highly satisfied, 56 customers are satisfied and 104 customers are neutral. For this reason, the mean value is only $63 \%$, which is almost nearest to neutral position.

\section{Availability of bank's booth}

Customers want to use the booth of their own bank and its availability is a key factor for satisfaction. This study shows that most of the customers are in satisfied and highly satisfied level. The mean value is $67.8 \%$. The result also indicates most of the banks have available ATM booth and customers get the access to use it from anywhere. 


\section{Weighted Average Satisfaction of the debit card Users (WAS)}

$* *$ Here, $w_{i}=$ weight to each satisfaction in factor, $f_{i}=$ mean value in percentage of each factor.

The weighted mean value for all the factors of satisfaction is $70.30 \%$, which lies in (value =4). It means Debit card users are satisfied. So, it can be said that all the banks are performing well in their debit card services. But to make customers highly satisfied, some strategies can be adopted.

\section{CONCLUSION AND RECOMMENDATIONS}

\subsection{Conclusion}

Banking sector is the most competitive sector in the present business world. Thousands of customers are served by banks. Ultimate goal of the bank is to maximize the wealth of the owners. To achieve this goal, attention must be given to service quality. When debit card users are satisfied, they will be attached to the bank for a long time. It will be strength for a specific bank to compete with other banks. It will help the growth of the debit card users' confidence on the bank and users will be tempted. If banks want to sustain positively, there is no alternative but to satisfy the customers, especially the debit card users, because they use it against their valuable deposited money in the bank. Bank must improve its strategies to fill up the demand of Debit card users because if the users switch to another bank, the particular bank will lose some cash flow that will negatively affect the goal of the bank. It is hoped that all the banks will come forward to think about this matter.

\subsection{Recommendations}

For better debit card service, the following strategies are recommended:

- Banks should improve the network service quality so that customers are not refused when they go to ATM booth.

- As customers want to be updated about their account balance, debit card transaction should provide receipt always.

- Banks should increase their own booth. As own booth is cost free, customers always prefer to use it.

- Some customers have recommended that banks should reduce the transaction cost of Debit card. They have to pay this cost when use other bank's ATM booth. 
- Banks can make agreement with shopping centers so that customers can easily use Debit card at those places. This arrangement will help reduce the hazards of purchasing.

- Sometimes customers do not get Taka from booth though that is automatically reduced from their account. This is a main factor for users' dissatisfaction. Banks can take initiatives to solve this problem promptly.

- As users need different value denominated notes, banks should keep most of the value denominated notes in the booth (Taka 100 multiples).

\section{REFERENCES}

Abedin, M. Jaynul. 1996. Hand Book of Research. Dhaka; Book Syndicate.

Banstola, Amir. 2007. "Prospects and Challenges of E-banking in Nepal." The Journal of Nepalese Business Studies, 4(1):96-97.

Huq, Muhammad Nazmul, Israt Jahan Tania.2005. "Measurement of Customer Satisfaction of Credit Card Users." Stamford University Journal of Business Studies, 01(1).

Islam, Md. Rafiqul, Samir Kumar Sheel, and Pallab Kumar Biswas. n.d. Customer Satisfaction of ATM Service: A Case Study of HSBC ATM." Available at http://ssrn.com/abstract=990242 , accessed on 22.02.2010.

Jabnoun, N., H.A.H Al-Tamimi. 2003. "Measuring Perceived Service Quality at UAE Commercial Banks." International Journal of Quality and Reliability Management, 20(4):458-72.

Khan, Md. Asif. 2010. "An Empirical Study of Automated Teller Machine Services Quality and Customer Satisfaction in Pakistani Banks." European Journal of Social Sciences, 13(3):333-334.

Mobarek, Asma. "E-Banking Practices and Customer Satisfaction: A Case Study in Botswana." Available at http://ssrn.com/abstract $=1011112$, accessed on 25.02.2010.

Shamsuddoha, Mohammad. "Development of Electronic Banking in Bangladesh." Available at:http//ssrn.com/abstract=.1302296, accessed on 15.03.2010.

Shamsuddoha, Mohammad, T. Md Chowdhury, and A.B.M.J Ahsan. "Automated Teller Machine: a New Dimension in the Bank Services of Bangladesh." Available at:http//ssrn.com/abstract=.1302301, accessed on 17.03.2010.

Websites

www.abbank.com.bd

www.bracbank.com

www.dutchbanglabank.com 
www.ebl-bd.com

www.mblbd.com

www.primebank.com.bd

www.shahjalalbank.com.bd

www.standardchartered.com

www.thecitybank.com.bd

\section{APPENDICES}

APPENDIX TABLE 1 BANKS OWN BOOTH POSITION

\begin{tabular}{ccc}
\hline Answer & Frequency & Percentage \\
\hline Yes & 152 & $76 \%$ \\
No & 48 & 24 \\
\hline
\end{tabular}

Source: Own Survey.

APPENDIX TABLE 2

DURATION OF USING DEBIT CARD USE

\begin{tabular}{l|c|c}
\hline \multicolumn{1}{c|}{ Time } & Frequency & Percentage \\
\hline Up to 1 year & 78 & $39 \%$ \\
1-2 years & 86 & 43 \\
3-4 years & 36 & 18 \\
5 years and above & 0 & 0
\end{tabular}

Source: Own Survey.

APPENDIX TABLE 3

TIMES OF TRANSACTION PER MONTH

\begin{tabular}{l|c|c}
\hline \multicolumn{1}{c|}{ Times } & Frequency & Percentage \\
\hline $1-2$ times & 80 & 40 \\
3 & 34 & 17 \\
4 & 26 & 13 \\
Above 4 times & 60 & 30 \\
\hline
\end{tabular}

Source: Own Survey. 
APPENDIX TABLE 4 NATURE OF PROBLEM CUSTOMERS FACED

\begin{tabular}{lc}
\hline \multicolumn{1}{c}{ Problem faced } & Frequency \\
\hline Unavailability of taka in the booth & 112 \\
Unavailability of receipt & 112 \\
Unavailability of small value denominated note & 78 \\
Fake note & 4 \\
Receipt was got but not taka & 34 \\
\hline
\end{tabular}
Source: Own Survey.

APPENDIX TABLE 5 NAME OF THE PROBLEM BANK WITH FREQUENCY OF PROBLEM

\begin{tabular}{l|c|c}
\hline \multicolumn{1}{c|}{ Bank's name } & Frequency of problem & Percentage \\
\hline EBL & 36 & 18 \\
DBBL & 108 & 54 \\
PBL & 20 & 10 \\
ABBL & 24 & 12 \\
BBL & 16 & 8 \\
\hline
\end{tabular}

Source : Own Survey.

APPENDIX TABLE 6

CAUSE OF CUSTOMERS' INTEREST TO USE DEBIT CARD

\begin{tabular}{l|c}
\multicolumn{1}{c|}{ Cause } & Frequency \\
\hline Time saving & 92 \\
Instant transaction & 46 \\
Easy to use & 50 \\
Other cause & 12 \\
\hline
\end{tabular}

Source: Own Survey. 
APPENDIX TABLE 7

MEAN VALUE OF SATISFACTION REGARDING AVAILABILITY OF TAKA IN THE BOOTH

\begin{tabular}{l|l|l|l|l}
\hline $\begin{array}{c}\text { Satisfaction } \\
\text { level }\end{array}$ & $\begin{array}{c}\text { Value of } \\
\text { satisfaction level } \\
(x)\end{array}$ & Frequency $(f)$ & $d=x-A$ & $f d$ \\
\hline HD & 1 & 0 & -2 & 0 \\
$\mathrm{D}$ & 2 & 18 & -1 & -18 \\
$\mathrm{~N}$ & $3=\mathrm{A}$ & 30 & 0 & 0 \\
$\mathrm{~S}$ & 4 & 126 & 1 & 126 \\
$\mathrm{HS}$ & 5 & 26 & 2 & 52 \\
Total & & $\sum f=200$ & & $\sum f d=160$ \\
\hline
\end{tabular}

Note: All other factor specific means are calculated in the same way

$$
\begin{aligned}
\bar{x} & =\left(A+\frac{\sum f d}{\sum f}\right) \times C \\
& =\left(3+\frac{160}{200}\right) \times 20 \% \\
& =76 \%
\end{aligned}
$$

